\title{
CONCEPTS IN EARLY SENSORY DEVELOPMENT
}

\author{
SARAH FORSYTH BLACHA, O.T.(C)*
}

\section{SUMMARY}

Various factors which contribute to perceptual development and the close relationship of sensorl and motor influences 10 normal development are discussed in the hope of encouraging therapists who w'ork in the developmental field to incorporate appropriate, graded sensorl stimuli into their treatment repertoire. The sensorl-motor link and the importance of tactile and vestibular sistems to the normal development of a percepiual schema are discussed.

The integration of sensory input is essential to normal motor development. When an infant is deprived of sensory stimulus, the impact on motor and perceptual/cognitive development is devastating (Casler, 1968), subsequently handicapping the child in understanding and interacting with his environment.

Two widely recognized approaches, Sensory Integrative Therapy (Ayres, 1972, 1975) and Neurodevelopmental Therapy (Bobath, 1971; Bobath and Bobath. 1975) emphasize sensory awareness and input in their therapy models to produce appropriate motor and/or adaptive behavioural responses.

The integration of sensory and motor information occurs at various levels of the central nervous system (CNS). All incoming information is processed by the CNS and sensory feedback is received from the body musculature to help organize motor output. This sensory-motor-sensory processing provides the basis for motor learning which, as Moore (1972) noted, may be either conscious or unconscious. Since therapy in young children frequently attempts to activate or elicit unconscious responses, consideration must be given to the effects of sensory input received during treatment.

Movement, which occurs at both an automatic and a voluntary level (conscious and unconscious), is essential to the development of body image and, thus. our ability to respond to the environment. Perception of form and space is dependent on freedom of movement. In a study of physically handicapped children, Wedell et al. (1972) found a high correlation between a lack of independent mobility and inability to perceive size constancy at a distance. To develop concepts of form, the child must not only view an object as it is presented; he must also move around it and perhaps move it around. Children with neuromotor disorders are often deprived of these learning opportunities and may receive distorted feedback because of their limited independent mobility or abnormal movement patterns. In preparing children to obtain information independently, therapists must control abnormal movement through "handling" to minimize the potential for distorting sensory motor learning.

The close link between movement and vestibular input is important when planning therapy programmes. Since all personnel dealing with children provide vestibular input whether deliberately or not, its effect on the developing child

* Occupational Therapist

The Occupational Therapy Department, The Hospital for Sick Children, Toronto, Ontario, Canada

Received 28 October 1982.

\section{OPSOMMING}

Verskeie faktore wat bydrae lor perseptuele oniwikkeling en die nou verband van sensoriese en motoriese invloede tot normale onrwikkeling, word bespreek. Dit is om terapeute, wat mel kinders met vertraagde ontwikkeling werk, aan te moedig om toepaslike, gegradeerde sensoriese stimuli in hul behandelingsrepertoire insluit. Die sensoriese molorskakel en die belang van die taktiele en vestibulêre stelsels vir die normale ontwikkeling van perseptuele skema word bespreek.

also requires close examination. Moore (1972) noted that the vestibular system has phylogenetic links with most of the major systems in the body. Ayres (1975) includes specifiof vestibular therapy as an integral part of the treatment model. Ambulatory children seek vestibular input in their use of playground equipment, swings and merry-go-rounds as well as their activities, for example. rough housing play, jumping on beds and climbing furniture and trees.

Chee et al. (1978) studied the effects of specific vestibular stimulation on children with cerebral palsy and demonstrated an overall improvement in motor behaviour over the control group. However, further investigation is needed to identify the long-term impact on vestibulo-ocular function and other systems connected with vestibular function, especially in infants.

\section{SENSORY MOTOR SENSORY LEARNING}

Sensory motor learning coupled with innate biological factors assists the normally developing child to acquire skills in antigravity mobility and initial concepts of body schema, form and space. For many years therapists viewed motor skills and sensory input as separate entities but it is now known that some true sensory-motor tracts exist within the CNS (Wall. 1970: Kornhuber, 1975).

Sensory input is received through exteroceptive, proprioceptive and interoceptive receptors throughout the body. The normal CNS integrates external information with feedback about motor or chemical reactions made if response to a given stimulus. This ongoing integrative process contributes to normal development.

In the normal person, exteroceptive receptors obtain information from the external world which they transmit to the brain where it is integrated with sensory feedback as well as previously stored perception. When the message is interpreted an appropriate automatic postural response (righting and equilibrium reactions) is coupled with planned motor responses, which of ten incorporate cognitive and linguistic domains.

The CNS instantly receives sensory feedback about the accuracy of the response so that any necessary adaptation can be made. Through this continual sensory-motor-sensory cycle children learn about themselves and their environment, and develop the perceptual foundations required for higher cognitive learning.

\section{TACTILE SYSTEM}

The tactile system incorporates exteroceptive touch and proprioceptive and kinesthesiatic information which is carried to the CNS. 
Ayres (1975) has divided the tactile system into the protective and discriminatory systems. The protective system is phylogenetically very old and highly devcloped in the newborn infant. It warns of potential harm and produces various responses, such as "fight or flight" notor reactions.

The discriminatory system provides information about the nature. quality, quantity and arrangement of stimuli. It gives precise tactile input about time and space. Through the combined cffects of touch proprioception and kinesthesia the child develops body image and awareness of spatial relationships. The phylogenetically newer discriminatory sustem modulates the effects of and responses to stimuli received through the protective system (spinothalamic tracts).

\section{DEVELOPMENTAL, SEQUENCE}

In early development, the protective system is highly active in detecting pain and temperature. The newborn is acutely aware of hard and firm pressure. His responses to hight touch are initially nonspecific or generalized unless the light touch is rapid or unexpected in which case the appropriate response will be one of protection. Gradually the child learns to give a less generalized response and in so doing develops an awareness ol specilic body parts so that he can be visually attentive to then and eventually localize the stimulated area with his hands.

The discriminative system progresses sequentially. The newborn demonstrates his awareness of input by increasing his activity level or attention/orienting until he can localize touch through vision. He progresses to developing manual form and space perception initially by mouthing objects and later, when upper extremity skilis are adequate, by manipulating them within his visual field. As his cognitive abilities develop he distinguishes objects through stereognosis or touch alone and later through gra phesthesia, i.c. by discriminating shapes drawn on the skin.

A balance is necessary between the protective and discriminatory systems for somatosensory events to be transmitted simulaneously and interpreted accurately. An imbalance is seen in children with disturbance in the somatosensory process or tactile defensiveness (Ayres, 1975).

Taçtile input has major social and emotional implications establishing the child's identity and security within his

Pricis nvironment. When mobility and subsequently touch and pressure are restricted. the touch pressure receptors adapt very quickly, decreasing afferent flow to the CNS. From a developmental treatment vicwpoint, it is important not only to maintain the balance between the protective and discriminatory systems but also to provide adequate mobility so that proprioceptive and kinesthetic feedback can be integrated in developing perceptual domains.

\section{VESTIBULAR SYSTEM}

The vestibular system. which is phylogenctically old, detects speed and direction of movement and may even stimulate movement in utero (Wyke. 1975). Because of its many neural connections it is essential in developing postural security against gravity, distinguishing movement originating within the self from that originating in the surrounding visual field and developing a fluid body schema as opposed to a static body image. It affects postural tonc, especially in the cervical area.

The vestibular system or movement is essential for arousal and inhibition of the CNS through its conncctions to the retricular activating system. It is also necessary for the development of concepts about the self and our relationship to our environment, and the ability to sequence high-level tasks.

The integration of vestibular functions with tactile and visuat input occurs early in the development of righting and equilibrium reactions. This close link between movement and somatosensory information is a major prerequisite for normal antigravity mobility.

The combined effect of all sensory input results in a developmental progression of perceptual schemas. Initially the normal child comes to know how one part of his body relates to another and how it relates to gravity. Later he develops concepts of laterality, directionality and spatial relationships. Eventually. by accurately judging distance, size. shape and form. the child can move freely. At this stage these concepts are further refined and the child gains the ability to attend to a particular stimulus in the midst of many.

Normally, the initial perceptual processes are developed as a result of sensory and motor integration, but they must be linked to meaningful experiences to be integrated.

\section{FUNCTIONAI APPLICATION OF SENSORY DEVELOPMENT}

The normal, developing infant is exposed to varied tactile. vestibular, visual and auditory input when his mother cuddles and rocks him after he has been fed. When he is awake his palents talk to him. High frequency human speech, varicty of speed. pitch and rhythm will increase his attention. Parents also increase their body's sensory awareness of the parts of his body by kissing and stroking his feet and hands, thus affecting his level of alcrtness through vestibular and proprioceptive stimulation (Korner and Thoman, 1972). If the child's spatial orientation is altered and an appropriate stimulus is presented, visual attentiveness can be increased.

Brazelton (1973) discussed various adaptive behaviours neonates use in dealing with their environment, such as the ability to self quieten. In addition. infants control the input they receive from their parents by the response they make to the parent's overtures. For example, wriggling or crying usually persuades the parents to change the type of input they are giving. Awareness of behavioural responses is especially important when treating infants with ncurodevelopmental disorders.

As the normal infant grows he acquires a greater repertoire of more or less rand om movements that bring him into contact with his own body. When he bobs his head up and down while lying prone or being held he will attempt to fix on visually interesting objects; his neck proprioceptors and vestibular-ocular receptors send ongoing fecdback to the CNS about the normal position of the head and eyes in space. The visual system is extremely important in controlling the head and its movements. For this reason, the child must practice controlling his eyc movements while rcceiving vestibular input or, in more basic terms, while practising head control.

The normal child can put his hands to his mouth when he is 2 to 3 months old. While lying supine he will watch his hands, thus connecting tactile, visual, proprioceptive and kinesthetic information to achieve early sensory awareness of the upper extremities. Latcr, as he holds objects or attempts to reach for them, he becomes aware of the relationship bctween his upper extremities and the environment. Once basic grasping abilities are present he will 
explore objects visually and orally. This exploration is essential for the development of awareness of shape, size and taste with its emotional associations with nutritive and nonnutritive sucking. As motor skills are refined, skilled manipulation is used to explore objects within the visual and tactile domains. Although we may provide the abnormal child with varied somatosensory experiences. the normal child goes far beyond this by experiencing things such as earth, wood, flowers, etc., as he investigates his environment.

As the nervous system matures and neuromuscular control improves and each act is repeated many times, the actions will have increasing accuracy and intention. As the child's sensory awareness of his upper extremity and his body's symmetry increases he also learns that his upper torso orients about a central axis and begins to develop a midline orientation. Weight bearing gains reality for him and he discovers that he can use a supporting surface to initiate movement. Throughout all of this he discovers how the parts of his body move in a co-ordinated independent fashion.

Further sensory awareness is gained through exploratory play. Manipulative and visual skills are used to distinguish the form of an object. Gradually, the child learns to match similar objects, then to attach a meaning to an object and later to give objects symbolic labels. Much of this development depends on the child's ability to move around his environment independently and reach for objects of interest. As the child's CNS matures, the sensory information he receives becomes meaningful and integrated so that he develops an increasingly more sophisticated awareness of his body and the world around him.

Mobility and movement in space with body on bodyrighting reactions develop and the child starts to roll around a central axis, further developing the midline orientation. Gradually he learns sequenced movement such as crawling. which requires the use of counter rotation. and finally pulling to standing so that he can achieve antigravity mobility. This progression requires constant sensory input about body orientation in a variety of planes as well as the integrated use of righting and equilibrium reactions, which are an automatic motor response to a given sensory stimulus.

Once the child has achieved independent mobility he has simultaneously developed many of the perceptual prerequisites upon which he can start to develop more complex perceptual schema and cognitive function.

In conclusion it is essential for therapists dealing with CNS-damaged children to be aware of sensory domains and how they influence motor output at both an automatic and a motor planning level. As it is motoric independence that will allow the child to explore his environment and become a functional adult, our therapy must incorporate age appropriate and graded sensory stimulus related to a functional task that can be integrated and retained for future use.

\section{References}

Ayres, A. J. (1972). Sensory integration and learning disorders. Western Psychological Services, Los Angeles. Ayres, A. J. (1975). Sensorimotor foundations of academic ability, Eds. Cruickshank, W. M. and Hallahan, D. P. in: Perceptual and Learning Disabilities in Children, Vol. 2: Research and Theory. Syracuse University Press. Syracuse, N. Y., pp. 301-358.

Bobath, B. (1971). Motor development, its effect on general development, and application to the treatment of cerebral palsy. Phisiotherapy; 57, 526-532.

Bobath, B. and Bobath, K. (1975). Motor development in the different types of Cerebral Palsy. William Heinmann Medical Books Ltd, London.

Brazelton, T. B. (1973). Neonatal Behavioral Assessment Scale. Clinics in Developmental Medicine No. 50. J. B. Lippincott, Philadelphia.

Casler, L. (1968). Perceptual deprivation in institutional settings, Ed. Newton. G. in: Early Experience and Behavior, the Psychobiology of Development. Charles C. Thomas, Springfield, pp. 573-626.

Chee, F. K., Kreutzberg, J, R. and Clark, D. L. (1978). Semicircular canal stimulation in cerebral palsied children. Phys. Ther., 58, $1071^{\prime}-1075$.

Korner, A. F, and Thoman, E: B. (1972). The relative efficacy of contact and vestibular-proprioceptive stimulation in soothing neonates. Child Dev., 43, 443-453.

Kornhuber, H. H. (Ed.) (1975). The Somatosensory System. Publishing Sciences Group. Acton, Massachusetts.

Moore. J. C. (1972). Cranial nerves and their importance in current rehabilitation techniques, in: The Body Senses and Perceptual Deficits. Proceedings of Occupational Therapy Symposium, Boston University, Massachusetts, pp. $102-120$.

Wall. P. D. (1970). The sensory and motor role of impulses travelling in the dorsal columns toward cerebral cortex. Brain, 93. 505-524.

Wedell, K., Newman, C. V., Reid, P. and Bradbury, I. R. (1972). An exploratory study of the relationship between size constancy and experience of mobility in cerebral palsied children. Dev. Med. Child Neurol., 14, 615-620.

Wyke. B. (1975). The neurological basis of movement - a developmental review, Ed. Holt, K. S. in: Movement and Child Development. Clinics in Developmental Medicine No. 55. William Heinmann, London, pp. 19-33. 